\section{Basic and Applied Ecology}

www.elsevier.de/baae

\title{
Large herbivore grazing and invertebrates in an alpine ecosystem
}

\author{
Atle Mysterud ${ }^{\mathrm{a}, *}$, Ragnar Aaserud ${ }^{\mathrm{a}}$, Lars Ove Hansen ${ }^{\mathrm{b}}, \mathrm{Kjetil}^{\AA} \mathrm{kra}^{\mathrm{c}}$, \\ Stefan Olberg ${ }^{\mathrm{d}}$, Gunnar Austrheim ${ }^{\mathrm{e}}$ \\ ${ }^{a}$ Centre for Ecological and Evolutionary Synthesis (CEES), Department of Biology, University of Oslo, \\ P.O. Box 1066 Blindern, NO-0316 Oslo, Norway \\ ${ }^{\mathrm{b}}$ Natural History Museum, University of Oslo, P.O. Box 1172 Blindern, NO-0318 Oslo, Norway \\ ${ }^{\mathrm{c}}$ Midt Troms museum, Pb. 82, NO-9050 Storsteinnes, Norway \\ ${ }^{\mathrm{d} B i o f o k u s, \text { Gaustadalléen 21, NO-0349 Oslo, Norway }}$ \\ ${ }^{\mathrm{e}}$ Museum of Natural History and Archeology, Section of Natural History, \\ Norwegian University of Science and Technology, Trondheim NO-7491 Norway
}

Received 30 June 2009; accepted 2 February 2010

\begin{abstract}
The literature on how plants respond to grazing and other disturbance factors have advanced greatly in recent decades, but studies of invertebrates are comparably few. We here quantify the effects of 3 levels of sheep grazing on selected invertebrates in an alpine ecosystem in Norway. We tested the hypothesis that invertebrates are more sensitive to grazing than plants (responding mainly at high density), and that primary consumers (herbivorous beetles) are more sensitive than predatory species (beetles and spiders). We captured 1218 specimens belonging to 44 beetle species and 6672 specimens belonging to 66 species of spiders. The community was dominated by few species: 5 beetle and 3 spider species made up $53.0 \%$ and $37.4 \%$ of the catch, respectively. At the local (plot) scale, most negative responses were only recorded at high sheep density, and invertebrates were thus not more responsive than the plant community. Two dominant herbivorous beetles responded to grazing while 3 dominant species of predatory beetles did not (one marginally). Spider species richness and frequency of occurrence of 2 dominant species were negatively affected by sheep grazing, suggesting variation between different taxonomic groups of predators. Further functional details than simple classification like herbivorous, predatory and litter-dwelling invertebrates seem to be required before a framework to predict responses to disturbance are robust.
\end{abstract}

\section{Zusammenfassung}

In den letzten Dekaden haben die Veröffentlichungen darüber zugenommen, wie Pflanzen auf Beweidung und andere störende Faktoren reagieren, Untersuchungen in Bezug auf Invertebraten sind jedoch vergleichsweise selten. An dieser Stelle quantifizieren wir die Effekte von 3 Intensitäten der Schafsbeweidung auf ausgewählte Invertebraten eines alpinen Ökosystems in Norwegen. Wir untersuchten die Hypothese, dass die Invertebraten gegenüber der Beweidung empfindlicher sind als die Pflanzen (die hauptsächlich bei hohen Dichten reagieren), und dass die primären Konsumenten (herbivore Käfer) empfindlicher sind als räuberische Arten (Käfer und Spinnen). Wir fingen 1218 Individuen, die zu 44 Käferarten, und 6672 Individuen, die zu 66 Spinnenarten gehörten. Die Lebensgemeinschaft wurde

\footnotetext{
*Corresponding author. Tel.: +47 228540 45; fax: +4722854726

E-mail address: atle.mysterud@bio.uio.no (A. Mysterud).
} 
durch wenige Arten dominiert: 5 Käfer- und 3 Spinnenarten machten 53,0 bzw. 37,4\% der Fänge aus. Auf der lokalen Ebene (Probefläche) wurden die meisten negativen Effekte nur bei intensiver Schafbeweidung festgestellt, und die Invertebraten reagieren demnach nicht stärker als die Pflanzengemeinschaft. Zwei der dominanten herbivoren Käferarten reagierten auf die Beweidung, während 3 der dominanten räuberischen Käferarten nicht (oder nur marginal) reagierten. Der Artenreichtum der Spinnen und die Häufigkeit des Auftretens wurden bei zwei dominanten Arten negativ durch die Schafbeweidung beeinflusst, und lassen eine Variation bei unterschiedlichen taxonomischen Gruppen von Prädatoren vermuten. Neben den einfachen Klassifikationen in herbivore, räuberische und streunutzende Invertebraten werden weitere funktionale Einzelheiten benötigt, um das Rahmenwerk für die Vorhersage der Reaktionen auf Störungen robust zu machen.

(C) 2010 Gesellschaft für Ökologie. Published by Elsevier GmbH. All rights reserved.

Keywords: Beetles; Ecosystem function; Sheep; Spiders; Vectorized general linear models

\section{Introduction}

There is currently increasing interest in studies of ecosystem effects of grazing by large herbivores both from a theoretical and an applied viewpoint (reviews Stewart, 2001; Côté, Rooney, Trembley, Dussault, \& Waller, 2004; Danell, Bergström, Duncan, \& Pastor, 2006). The state of affairs for this field is illustrated by a recent book on large herbivore ecology and ecosystem dynamics (Danell et al., 2006), with 8 chapters on either nutrient cycling and/or plant responses to grazing, while only 1 chapter reviewed effects on "other fauna" (Suominen \& Danell, 2006). The approach of using plant functional groups has clearly advanced the foundation for making good predictions regarding mechanisms involved in disturbance effects in general (e.g., Lavorel, McIntyre, Landsberg, \& Forbes, 1997; Díaz et al., 2007; Violle et al., 2007). Currently, no similar theoretical framework is available to predict responses of invertebrates to large herbivore grazing. This is somewhat disturbing, since responses of invertebrates and plants are not only found to differ (Kruess $\&$ Tscharntke, 2002), but also that there is a weaker disturbance tolerance of insects compared with plants (Pöyry et al., 2006).

The responses to grazing vary markedly between groups of invertebrates (Gonzalez-Megias, Gomez, \& SanchesPinero, 2004; Sjödin, Bengtsson, \& Ekbom, 2008). With black-tailed deer (Odocoileus hemionus) in forest habitat, vegetation dwelling insects (primary consumers) were most affected, while litter-dwelling insects showed little or no variation related to browsing history (Allomberg, Stockton, $\&$ Martin, 2005). Herbivorous invertebrates can be affected directly by competition for forage, and the competitive effect may increase if plants have induced defenses (Karban \& Baldwin, 1997). Predatory species are expected to be affected through trophic interactions, if grazing reduces abundance of prey. Both herbivorous and predatory groups can clearly be affected by structural changes in their habitat, linked to structural characteristic of important tree or browse species (den Herder, Virtanen, \& Roininen, 2004), plant vegetation cover (Pringle, Young, Rubenstein, \& McCauley, 2007) and plant species richness (Kruess and Tscharntke, 2002). Vegetation structure plays a role also in grassland systems (Morris, 2000). Similarly to the field of plant responses to grazing (Austrheim et al., 2008; Evju, Austrheim, Halvorsen, \& Mysterud, 2009), the most common design is to compare grazed to ungrazed areas with little control over exact grazing levels, despite that this is a central key both theoretically and from a management perspective (Augustine \& McNaughton, 1998). There is thus a marked need of well-designed studies of responses to several grazing levels by invertebrates with an attempt for using functional groups.

In this study, we use 3 levels of sheep grazing $(0,25$ and 80 sheep per $\mathrm{km}^{2}$ ) in a fully replicated experimental set-up at a large spatial scale $\left(2.7 \mathrm{~km}^{2}\right)$. Our focal taxonomic invertebrate groups are spiders and beetles. Both spiders (Warui, Villet, Young, \& Jocqué, 2005) and beetles (Melis et al., 2006, 2007) seem sensitive to grazing, and responses may depend on ecosystem productivity (Suominen, Persson, Danell, Bergström, \& Pastor, 2008). We here contrast responses of dominant herbivorous vs. carnivorous beetles, as a starting point for a simple functional classification. We predict stronger responses in herbivorous than predatory species on a short-term scale (2 years), as primary consumers are reported to be most affected when compared to litter-dwelling species (Allomberg et al., 2005). As we found only moderate responses of vascular plants at high density after 2 years (Austrheim et al., 2008), we test the hypothesis that invertebrates are more sensitive to disturbance than plants (Sjödin et al., 2008), and we would take effects of low density of sheep as evidence of more sensitive responses.

\section{Materials and methods}

\section{Study area}

The study area is in Hol municipality, Buskerud county in the southern part of Norway (between $7^{\circ} 55^{\prime}-8^{\circ} 00^{\prime}$ and $60^{\circ} 40^{\prime}-60^{\circ} 45^{\prime}$ ) near the lake Strandavatnet (Mysterud \& Austrheim, 2005). The area is mainly in the lower alpine zone close to the forest line made up of birch (Betula pubescens). The upper limit just barely extends into the middle alpine zone characterized by a displacement of the dwarf-shrub Vaccinium myrtillus (Moen, 1998). The area has a sub-continental alpine climate with moderate to low annual precipitation (1000 mm, Evju et al., 2009). The bedrock 
consists of meta-arkose (Sigmond, 1998) and the soil is moderately base-rich. Low shrub heaths are the dominant vegetation types interspersed with grass-dominated meadows typically selected by sheep (Mobæk, Mysterud, Loe, Holand, \& Austrheim, 2009). A total of 104 vascular species were recorded in 180 plots (each of $0.25 \mathrm{~m}^{2}$ ) and herbs dominate (53\%; Austrheim, Evju, \& Mysterud, 2005). The biomass in dwarf-shrub communities is dominated by woody species (85\%) such as V. myrtillus, Empetrum nigrum and Phyllodoce caerulea, while graminoids $(6 \%)$, bryophytes and lichens $(8 \%)$ and herbs $(1 \%)$ are rarer. Grassland biomass is dominated by graminoids (47\%) such as Carex bigelowii and Deschampsia flexuosa, woody species (31\%), herbs (12\%) and bryophytes and lichens (9\%) (Mysterud and Austrheim, 2005).

\section{Experimental design}

Sheep grazing effects on invertebrates were studied within an experimental facility comprising a large enclosure covering $2.7 \mathrm{~km}^{2}$ and consists of 9 sub-enclosures (mean size $\left.0.3 \mathrm{~km}^{2}\right)$ separated by standard sheep fencing $(110 \mathrm{~cm} \mathrm{high})$ (e.g., Loe et al., 2007; Austrheim et al., 2008; Mobæk et al., 2009). The 9 sub-enclosures enabled use of a block-wise randomization design with 3 blocks (i.e., 3 replicates). Within each block, we randomly assigned the treatments "control" (no sheep), low (25 sheep per $\mathrm{km}^{2}$ ) and high (80 sheep per $\mathrm{km}^{2}$ ) density of sheep. Grazing levels were chosen to reflect common grazing levels on open ranges of Norway, and were based on advice by a grazing ecologist who mapped the vegetation of the area in 2001 and assessed its grazing value for sheep (Rekdal, 2001). Habitats with little or no forage were excluded when calculating density. Based on frequency of herbs eaten, the low and high density treatments correspond to low and moderate grazing pressures (Evju, Mysterud, \& Austrheim, 2006). The enclosure is situated on a south-facing slope, and all sub-enclosures span an approximately similar altitudinal range, extending from $1050 \mathrm{~m}$ to $1300 \mathrm{~m}$ a.s.1. (Mysterud, Iversen, \& Austrheim, 2007). Vegetation types are also fairly similar among the sub-enclosures (Rekdal, 2001). All sheep were of the "Kvit norsk sau" breed, the most common breed in Norway (Mysterud and Austrheim, 2005). Ewes averaged $83 \mathrm{~kg}$ in live weight (spring) and lambs averaged $19 \mathrm{~kg}$ in spring and $42 \mathrm{~kg}$ in autumn. The grazing treatment started in 2002, while this study was conducted in 2003. The grazing season was from the last week of June to first week of September in 2002 and last week of August in 2003, which is similar to the season for free ranging sheep in mountain regions in southern Norway (Mysterud and Austrheim, 2005).

\section{Plant community}

Data on the vascular plant community composition, plant height and coverage were collected within 180 plots (20 in each sub-enclosure, i.e. 60 in each block) each measuring $0.25 \mathrm{~m}^{2}$ in 2003 (Austrheim et al., 2008). The plots were randomly chosen with a balanced stratified distribution among habitats and altitudinal levels. Plant species abundance in each plot is based on presence-absence within 16 subplots $\left(0.0156 \mathrm{~m}^{2}\right)$, i.e. frequency data. The following parameters of the plant community were considered:

(1) DCAl scores. We used Detrended Correspondance Analysis (DCA) to extract information on the plant community (data as percentage and therefore arcsin (sqrt) transformed prior to analysis) from the vegetation plots in 2003 with detrending by segments, non-linear rescaling of ordination axes and downweighting of rare species (Hill \& Gauch, 1980). The first (DCA1; eigenvalue 0.517 ) axis explained $17.2 \%$ of the variation in the abundance of the plant species. The DCA1 scores correlate with variation in soil Nitrogen and $\mathrm{pH}$ as shown for the 2001 dataset (Austrheim et al., 2008). We used DCA1 scores in further analyses as a gross representation of the vegetation community, as it reflects the main variation in plant community composition at the plot scale. A low DCA1 value indicates mainly grass-dominated vegetation types (such as snow beds and tall herb meadow), intermediate values with more shrub species (dwarfshrub heath vegetation) ending in lichens heaths for the highest values.

(2) Plant species richness. The number of vascular plant species recorded at a plot (ln-transformed). A previous study (Mysterud, Hansen, Peters, \& Austrheim, 2005) documented a high correlation $\left(r_{\text {Pearson }}=0.988\right)$ between plant species richness and functional richness (based on the taxonomic distinctness index, Clarke \& Warwick, 1998). We therefore retained only plant species richness here.

We also used data on (3) vascular plant cover (\%) and (4) plant height $(\mathrm{cm})$ to characterize the vegetation. Vascular plant cover was estimated by visually assessing the coverage (done by the same person for all sites). Plant height was measured as height of the dominating strata within $5 \mathrm{~cm}$ intervals, as there was a marked height structure of the vegetation in this alpine habitat (Steen, Mysterud, \& Austrheim, 2005), and since plant height is important especially to folivorous invertebrates (Morris, 2000).

\section{Invertebrate sampling and taxonomic classification}

Samples were taken adjacent to the 180 vegetation plots over 3 periods (Fig. S1). It took 3 days to cover all 180 plots. Pitfall traps were put out 24-26 June 2003. The 1 st period is the catch until 21-23 July, the 2nd period from this until 11-13 August, and the 3rd period from this until 5-7 September. Traps were plastic cups of $6.8 \mathrm{~cm}$ in diameter and $9.0 \mathrm{~cm}$ in depth dig into the ground. Hard plastic 
covers were placed over each trap to limit the effect of trampling and to reduce the risk of flooding during heavy rain. We used a mixture of 4/5 of water and 1/5 of ethylenglycol and added a squirt of soap (Zalo) in the barber traps to prevent the invertebrates from escaping or decomposing. Pitfall traps are a common method of sampling ground-living terrestrial arthropods. The method is reported sensitive to species differences in trapability (e.g., Uetz \& Unzicker, 1976), but this is unlikely to result in differences between grazing levels or periods, and therefore regarded suitable for our purpose. Spiders and beetles were separated from the catch and stored in $70 \%$ ethanol. Specimens were identified down to species level by experts in spider (Kjetil Aakra) and beetle (Stefan Olberg) taxonomy. The number of individuals of all species was counted for each sample. We classified beetles into wide functional groups. Our focus is on herbivorous and predatory beetles, while coprophilous and fungivorous beetles had too low abundances to allow more detailed analysis.

\section{Statistical analysis}

The main challenge in the analysis is the high number of zero observations (cfr. Martin et al., 2005), which gives a poor fit when ordinary poisson models are used. We solved this challenge in 2 different ways depending on the distribution of the data.

Abundance data of beetles and spiders at the species level were dominated largely by 0 and 1 . We therefore used logistic regression with a binomial error (all observations $\geq 1$ pooled). We used generalized linear mixed models with "sub-enclosure" as a random effect to account for the non-independency of observations (Lindsey, 1999; Crawley, 2003) using library "Ime4" in R. We assessed goodness-of-fit of the final model (without the random term) using the sum of squares test (Le Cessie \& Van Houwelingen, 1991) using the library "Design" in R (Harrell, 2001).

The data on species richness of spiders and beetles also had high numbers of zeroes, but there was a considerably longer tail in the abundance distribution (much of the data $>1$ ). We therefore used zero-inflated poisson models within the vectorized general linear models (VGLM) framework of library "VGAM" in R (http://www.stat.auckland.ac.nz/ yee). VGLM provide 2 parameter estimates for each term; one for the zeroproportion and the other for the poisson parameters (see e.g., in Rødven, Männikkö, Ims, Yoccoz, \& Folstad, 2009). The VGLM do not open for the inclusion of random terms. Variation in abundances may create bias in species richness comparisons (Sanders, 1968; Hurlbert, 1971; review in Gotelli \& Colwell, 2001). We performed an individualbased rarefaction analysis to explore the robustness of the species richness analysis at the plot scale ( $\alpha$-diversity) using the library "vegan" in R. We used a sample-based rarefaction approach for assessing overall species richness ( $\gamma$-diversity) using the Mau Tau method implemented in EstimateS vs. Win 8.20 (Colwell, 2009).
We used the Akaike Information Criterion (AIC) for guiding model selection (Burnham \& Anderson, 2002). We used manual selection starting with the full model (only main effects). Only the best models are presented. All analyses were performed in R v. 2.8.0 (R. Development Core Team, 2008), except DCA, which was calculated in CANOCO v. 4.5 (Ter Braak \& Smilauer, 2002).

\section{Results}

The total catch comprised 1218 specimens belonging to 44 species of beetles (Table S1) and 6672 specimens belonging to 66 species of spiders (Table S2). Overall species richness of beetles and spiders ( $\gamma$-diversity) was even among treatments (overlapping 95\% confidence intervals, Fig. S2). At the plot scale ( $\alpha$-diversity), both beetle richness and spider richness were markedly negatively affected by density of sheep (Table 1), with the largest (and significant) effect of high density of sheep (Fig. 1). These results were robust when performing an individual-based rarefaction procedure. Only sheep density and period were included in the best model of spider richness (Table S3), while the more complicated models for beetle richness failed to converge. The dominant beetle species Byrrhus fasciatus $(n=48)$, Patrobus assimilis $(n=150)$, Calathus melanocephalus $(n=210)$, Notiophilus aquaticus $(n=73)$ and Otiorynchus nodosus $(n=164)$ made up $53.0 \%$ of the total catch. The dominant spider species Pardosa palustris $(n=1901)$, Gonatium rubens $(n=207)$ and Gnaphosa leporina $(n=390)$ made up $37.4 \%$ of the total catch. The best models of the 2 herbivorous beetles both included the sheep grazing treatment (Table S2). High levels of sheep grazing lowered the frequency of occurrence of herbivorous beetles (B. fasciatus and $O$. nodosus; Table 2). The sheep density term did not enter the best models of predatory beetles (Table S4). For $P$. assimilis, the model including sheep density was competitive, and when estimated, the negative effect of high sheep grazing was close to significant ( $t=-1.845, P=0.065)$. For the 3 dominant spider species, sheep density did not enter the best models (Table S5). However, for 2 of the species, the model with sheep density was highly competitive (Table S5), and the negative effect of high sheep grazing was significant for $G$. rubens $(Z=-2.061$, $P=0.039)$ and marginally non-significant for $G$. leporina $(Z=-1.929, P=0.054)$. In all models, the strongest predictor was sampling period; with the frequency of occurrence decreasing from the first to the third sampling period.

Different descriptions of the plant community were included in the models for the different species (Tables 2 and 3). Plant community described by DCA1 entered best models for 4 of 5 beetle species (significant for 3 species) and 2 of 3 spider species (significant for 1 species). Plant height entered and was a significant negative predictor for all 3 spider species, but entered the best models for only 2 out of 5 beetle species being non-significant in both cases. Plant richness entered as a negative factor for both 
Table 1. Output from statistical analyses of effects of no, low and high sheep density on the beetle and spider species richness at local, plot scale in Hol, Norway during summer 2003 using vectorized general linear models (VGLM) with zero-inflated poisson function. Bold values are significant at $(p<0.05)$.

\begin{tabular}{|c|c|c|c|c|}
\hline Parameter & Estimate & SE & Lower $95 \% \mathrm{CL}$ & Upper $95 \%$ CL \\
\hline \multicolumn{5}{|l|}{ (A) Beetle species richness } \\
\hline Intercept: 1 & -1.8896 & 0.4888 & -2.8672 & -0.9121 \\
\hline Intercept: 2 & 0.9398 & 0.0872 & 0.7653 & 1.1142 \\
\hline Density (high vs. no): 1 & 1.2701 & 0.5598 & 0.1506 & 2.3896 \\
\hline Density (high vs. no): 2 & 0.0143 & 0.1217 & -0.2290 & 0.2577 \\
\hline Density (low vs. no): 1 & 0.9721 & 0.5615 & -0.1510 & 2.0951 \\
\hline Density (low vs. no): 2 & 0.1805 & 0.1105 & -0.0406 & 0.4015 \\
\hline Period (2nd vs. 1 st): 1 & -0.3654 & 0.4845 & -1.3343 & 0.6036 \\
\hline Period (2nd vs. 1 st): 2 & -0.8742 & 0.1222 & -1.1186 & -0.6298 \\
\hline Period (3rd vs. $1 \mathrm{st}): 1$ & -0.8943 & 1.2843 & -3.4629 & 1.6744 \\
\hline Period (3rd vs. 1st): 2 & -1.6581 & 0.1995 & -2.0572 & -1.2590 \\
\hline \multicolumn{5}{|l|}{ (B) Spider species richness } \\
\hline Intercept: 1 & -1.8222 & 0.2979 & -2.4179 & -1.2265 \\
\hline Intercept: 2 & 1.7430 & 0.0477 & 1.6475 & 1.8385 \\
\hline Density (high vs. no): 1 & 1.0864 & 0.3280 & 0.4304 & 1.7423 \\
\hline Density (high vs. no): 2 & -0.0410 & 0.0601 & -0.1613 & 0.0793 \\
\hline Density (low vs. no): 1 & 0.4022 & 0.3556 & -0.3090 & 1.1135 \\
\hline Density (low vs. no): 2 & -0.0240 & 0.0575 & -0.1391 & 0.0910 \\
\hline Period (2nd vs. 1 st): 1 & -0.7377 & 0.3247 & -1.3872 & -0.0882 \\
\hline Period (2nd vs. 1 st): 2 & -0.4971 & 0.0582 & -0.6136 & -0.3806 \\
\hline Period (3rd vs. $1 \mathrm{st}): 1$ & -0.3948 & 0.2962 & -0.9872 & 0.1977 \\
\hline Period (3rd vs. 1st): 2 & -0.5120 & 0.0595 & -0.6310 & $-\mathbf{0 . 3 9 3 0}$ \\
\hline
\end{tabular}

The first predictor estimate (1) is for the zero-proportion and the second (2) is for the poisson parameters. CL, confidence limit.
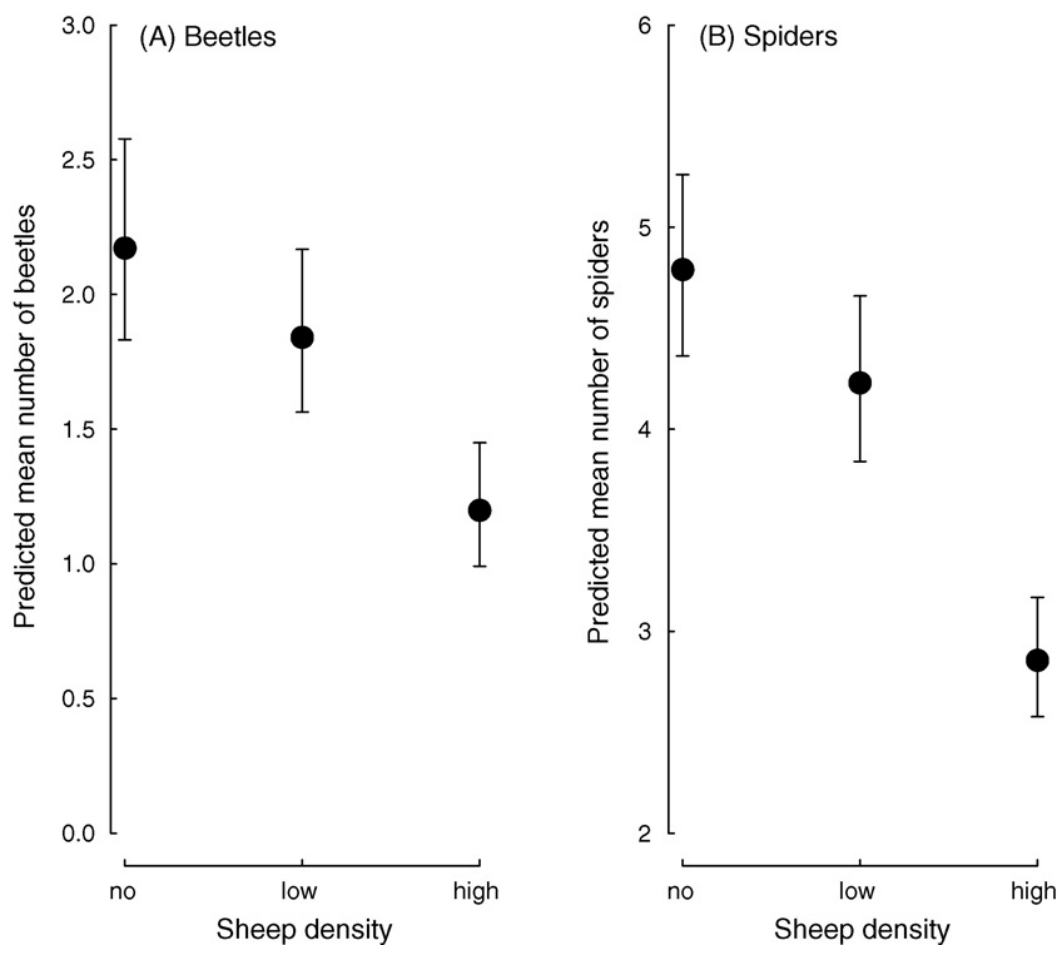

Fig. 1. The relationship between (A) beetle and (B) spider richness (local scale) and 3 experimental levels of sheep grazing in an alpine ecosystem in Hol, Norway. Values are predicted means and confidence intervals for the first sampling period from vectorized general linear models (VGLM) with a zero-inflated poisson function. Note that scales of $y$-axis differ between plots. 
Table 2. Output from statistical analyses of effects of no, low and high sheep density on the presence of the most common herbivorous and predatory beetle species captured in Hol, Norway for 3 periods during summer 2003. Bold values are significant at $(p<0.05)$.

\begin{tabular}{|c|c|c|c|c|c|c|}
\hline \multirow[t]{2}{*}{ Parameter } & & \multicolumn{2}{|c|}{ Byrrhus fasciatus } & & \multicolumn{2}{|c|}{ Otiorhynchus nodosus } \\
\hline & & Estimate & \multicolumn{2}{|l|}{ SE } & Estimate & SE \\
\hline Intercept & & 2.788 & \multicolumn{2}{|l|}{1.206} & 3.606 & 1.134 \\
\hline Density (high vs. no) & & -1.464 & \multicolumn{2}{|l|}{0.537} & -0.862 & 0.352 \\
\hline Density (low vs. no) & & -0.539 & \multicolumn{2}{|l|}{0.435} & -0.044 & 0.304 \\
\hline Period (2nd vs. 1st) & & -1.209 & \multicolumn{2}{|l|}{0.421} & -1.029 & 0.278 \\
\hline Period (3rd vs. 1st) & & -18.803 & \multicolumn{2}{|c|}{2066.43} & -3.396 & 0.612 \\
\hline \multicolumn{7}{|l|}{ Altitude } \\
\hline PlantDCA1 & & -0.930 & \multicolumn{2}{|l|}{0.236} & -0.316 & 0.167 \\
\hline Ln (plant richness) & & -0.907 & \multicolumn{2}{|l|}{0.343} & -0.909 & 0.260 \\
\hline \multicolumn{5}{|l|}{ Plant cover } & -0.021 & 0.009 \\
\hline & & & & & & \\
\hline \multirow[t]{4}{*}{ GOF } & & \multirow{2}{*}{$\begin{array}{l}\mathrm{Z} \\
-0.285\end{array}$} & $P$ & & $\mathrm{Z}$ & $P$ \\
\hline & & & 0.775 & & 0.307 & 0.759 \\
\hline & Patrobus & assimilis & Notiophilu & aticus & Calathus & cephalus \\
\hline & Estimate & SE & Estimate & SE & Estimate & SE \\
\hline Intercept & $-\mathbf{3 . 2 7 0}$ & 0.558 & -10.518 & 4.319 & 25.671 & 3.716 \\
\hline Density (high vs. no) & & & & & & \\
\hline Density (low vs. no) & & & & & & \\
\hline Period (2nd vs. 1st) & -1.580 & 0.310 & -0.056 & 0.337 & -1.369 & 0.365 \\
\hline Period (3rd vs. 1st) & -1.335 & 0.292 & -1.067 & 0.413 & -1.129 & 0.346 \\
\hline Altitude & & & 0.008 & 0.003 & -0.022 & 0.003 \\
\hline PlantDCA1 & & & -1.010 & 0.182 & -0.466 & 0.164 \\
\hline Ln (plant richness) & 0.858 & 0.226 & & & & \\
\hline Plant cover & & & & & & \\
\hline Plant height & 0.039 & 0.022 & 0.045 & 0.033 & & \\
\hline GOF & $\mathrm{Z}$ & $\mathrm{P}$ & $\mathrm{Z}$ & $\mathrm{P}$ & $\mathrm{Z}$ & $\mathrm{P}$ \\
\hline & 1.226 & 0.220 & 0.363 & 0.717 & 0.750 & 0.454 \\
\hline
\end{tabular}

Bold figures indicate that $95 \% \mathrm{CI}$ do not overlap with 0 . Only the most parsimonious models are fitted, so that missing values indicate that the respective factor did not enter the best model. "Sub-enclosure" was entered as a random term in all models. SE, standard error. GOF, goodness-of-fit $(P<0.05$ indicates a lack of fit).

Table 3. Output from statistical analyses of effects of no, low and high sheep density on the 3 most common spider species in Hol, Norway during summer 2003. Bold values are significant at $(p<0.05)$.

\begin{tabular}{|c|c|c|c|c|c|c|}
\hline \multirow[t]{2}{*}{ Parameter } & \multicolumn{2}{|c|}{ Pardosa palustris } & \multicolumn{2}{|c|}{ Gonatium rubens } & \multicolumn{2}{|c|}{ Gnaphosa leporina } \\
\hline & Estimate & SE & Estimate & SE & Estimate & SE \\
\hline Intercept & -13.863 & 2.762 & -0.652 & 0.742 & 1.048 & 0.295 \\
\hline Density (high vs. no) & & & -0.725 & 0.352 & -0.486 & 0.252 \\
\hline Density (low vs. no) & & & -0.241 & 0.328 & -0.075 & 0.246 \\
\hline Period (2nd vs. 1st) & -0.464 & 0.243 & 1.166 & 0.305 & -1.150 & 0.226 \\
\hline Period (3rd vs. 1st) & -0.719 & 0.244 & 1.317 & 0.303 & -2.462 & 0.290 \\
\hline Altitude & 0.012 & 0.002 & & & & \\
\hline PlantDCA1 & 0.273 & 0.103 & 0.189 & 0.117 & & \\
\hline Plant cover & & & -0.015 & 0.008 & & \\
\hline Plant height & -0.103 & 0.024 & -0.074 & 0.024 & -0.055 & 0.020 \\
\hline \multirow[t]{2}{*}{ GOF } & $\mathrm{Z}$ & $\mathrm{P}$ & $\mathrm{Z}$ & $\mathrm{P}$ & $\mathrm{Z}$ & $\mathrm{P}$ \\
\hline & -1.350 & 0.177 & 1.275 & 0.202 & 0.066 & 0.947 \\
\hline
\end{tabular}

Plant richness (ln) did not enter any of the best models. See Table 2 for further explanations. 
herbivorous beetles, but as a positive factor for 1 predatory species. Plant cover entered as a negative covariate for 1 beetle and 1 spider (Tables 2 and 3).

\section{Discussion}

We here demonstrate that occurrence of several invertebrate groups was quite markedly affected by sheep grazing. The main pattern was that only high density of sheep affected the invertebrate community, thus providing no solid support of the hypothesis that invertebrates as a group are more sensitive to disturbance than plants (Pöyry et al., 2006). The 2 dominant herbivorous beetles were more responsive than the 3 dominant predatory beetles. This is consistent with the hypothesis that primary consumer species should be more heavily affected (Allomberg et al., 2005). However, spider species richness was affected by sheep grazing despite that spiders are predators. This suggests that further functional details are needed to be able to successfully predict responses to grazing.

The literature of functional groups as a way to predict responses to grazing and other disturbances in plants has grown rapidly over the last 2 decades (Lavorel et al., 1997; Westoby, Falster, Moles, Vest, \& Wright, 2002; Westoby \& Wright, 2006; Díaz et al., 2007). There are a number of different axes or categories to classify plant species, and there is still a discussion about how much detail is needed. For example, simple traits [height, leaf size, growth form, life span and specific leaf area (SLA)] have different predictive value for grazing responses in different ecosystems (Vesk, Leishman, \& Westoby, 2004). The dominance of a few invertebrate species made a full comparative analysis using functional traits difficult in our case. A similar unbalance between species was also found in 2 other studies using pitfall traps, 1 on moose (Alces alces) browsing effects on beetles (Melis et al., 2007) and 1 on red deer (Cervus elaphus) grazing effects on beetles (Melis et al., 2006), with 10 species representing $98 \%$ of the catch in both cases. Clearly, conclusions drawn from only a handful of dominant species should be done with caution.

Our attempt to use a simple classification of functional groups of invertebrates (Allomberg et al., 2005) proved only partly successful. While responses of herbivorous were stronger than those of predatory beetles, the predatory spiders were also responsive to grazing. Clearly, the predatory behaviours of beetles and spiders differ markedly. Also, we were capturing mainly ground-living spiders being ambush predators not using nets, such as Lycosidae (Pardosa and Alopecosa) and Gnaphosidae (Gnaphosa). Also within the 2 groups of beetles there may be other important aspects of the ecology that differ. For example, 1 of our dominant predatory species $N$. aquaticus is known to occur mainly in moist areas (Melis et al., 2007), while B. fasciatus is more of a moss eater than the other herbivores. Capturing a wider suite of beetles and spiders with a broader range of functional traits would therefore be required to pursue the question of grazing responses and functional groups further.

In forest ecosystems in Norway and Finland, many beetles responded positively to browsing or grazing (Suominen, Niemelä, Martikainen, Niemelä, \& Kojola, 2003; Melis et al., 2006, 2007), which may suggest that simpler alpine habitats as in our case are more sensitive to disturbance. In forest ecosystems, browsing can largely impact plant height and overall tree architecture (De Jager \& Pastor, 2008), with huge impacts on invertebrate habitat. The plant communities in alpine ecosystems are characterized by dominance of plants of generally short stature and by the absence of trees (Körner, 2003). This study was conducted in the 2 nd season of grazing, before any marked changes in the vegetation composition (Austrheim et al., 2008). In our alpine ecosystem, plant community composition and structure nevertheless were important predictors of invertebrate occurrence. Also, inclusion of plant covariates strengthened markedly the responses to grazing by reducing variance. Description of the overall plant community (1st axis of a DCA) was a particularly important predictor for both spiders and beetles, while plant height seemed a more important predictor for spiders than for beetles. Both moose browsing and red deer grazing effects on ground beetle abundance and diversity in Norway were largely working through bilberry ( $V$. myrtillus) cover (Melis et al., 2006, 2007). Plant height may vary both between grazing treatments and between years (Evju et al., 2006), and more long-term grazing might affect the plant community descriptors used in our study. It is therefore likely to assume that longer term grazing would add further strength to the responses as the plant community changes.

\section{Acknowledgements}

This work was funded by the Research Council of Norway (Pr. 183268/S30) and Directorate for nature management (DN). We are grateful to 2 anonymous referees for very valuable comments to a previous draft, and to Nigel G. Yoccoz and Rolf Rødven for suggesting VGLM and for help with scripts for their implementation, and to Anders Nielsen for advice on using EstimateS.

\section{Appendix A. Supplementary data}

Supplementary data associated with this article can be found, in the online version, at doi:10.1016/j.baae. 2010.02.009.

\section{References}

Allomberg, S., Stockton, S., \& Martin, J.-L. (2005). A natural experiment on the impact of overabundant deer on forest invertebrates. Conservation Biology, 19, 1917-1929. 
Augustine, D. J., \& McNaughton, S. J. (1998). Ungulate effects on the functional species composition of plant communities: herbivore selectivity and plant tolerance. Journal of Wildlife Management, 62, 1165-1183.

Austrheim, G., Evju, M., \& Mysterud, A. (2005). Herb abundance and life history traits in two contrasting alpine habitats in southern Norway. Plant Ecology, 179, 217-229.

Austrheim, G., Mysterud, A., Pedersen, B., Halvorsen, R., Hassel, K., \& Evju, M. (2008). Large scale experimental effects of three levels of sheep densities on an alpine ecosystem. Oikos, 117, 837-846.

Burnham, K. P., \& Anderson, D. R. (2002). Model selection and multimodel inference. A practical information-theoretic approach. New York: Springer.

Clarke, K. R., \& Warwick, R. M. (1998). A taxonomic distinctness index and its statistical properties. Journal of Applied Ecology, $35,523-531$.

Colwell, R. K. (2009). EstimateS 8.2 user's guide. Statistical estimation of species richness and shared species from samples. Connecticut: University of Connecticut. http://viceroy. eeb.uconn.edu/EstimateS, http://viceroy.eeb.uconn.edu/Colwell

Côté, S. D., Rooney, T. P., Trembley, J.-P., Dussault, C., \& Waller, D. M. (2004). Ecological impacts of deer overabundance. Annual Review of Ecology System, 35, 113-147.

Crawley, M. J. (2003). Statistical computing. An introduction to data analysis using S-Plus. Chichester, West Sussex, England: John Wiley and Sons.

Danell, K., Bergström, R., Duncan, P., \& Pastor, J. (2006). Large herbivore ecology, ecosystem dynamics and conservation. Cambridge: Cambridge University Press.

De Jager, N. R., \& Pastor, J. (2008). Effects of moose Alces alces population density and site productivity on the canopy geometries of birch Betula pubescens and B-pendula and Scots pine Pinus sylvestris. Wildlife Biology, 14, 251-262.

den Herder, M., Virtanen, R., \& Roininen, H. (2004). Effects of reindeer browsing on tundra willow and its associated insect herbivores. Journal of Applied Ecology, 41, 870-879.

Díaz, S., Lavorel, S., McIntyre, S., Falczuk, V., Casanoves, S., Milchunas, D. G., et al. (2007). Plant trait responses to grazing - a global synthesis. Global Change Biology, 13, 313-341.

Evju, M., Austrheim, G., Halvorsen, R., \& Mysterud, A. (2009). Grazing responses in herbs in relation to herbivore selectivity and plant traits in an alpine ecosystem. Oecologia, 161, $77-85$.

Evju, M., Mysterud, A., Austrheim, G., \& Økland, R. H. (2006). Selecting herb species and traits as indicators of sheep grazing pressure in a Norwegian alpine habitat. Ecoscience, 13, 459-468.

Gonzalez-Megias, A., Gomez, J. M., \& Sanches-Pinero, F. (2004). Effects of ungulates on epigeal arthropods in Sierra Nevada National Park (southeast Spain). Biodiversity and Conservation, 13, 733-752.

Gotelli, N. J., \& Colwell, R. K. (2001). Quantifying biodiversity: procedures and pitfalls in the measurements and comparison of species richness. Ecology Letters, 4, 379-391.

Harrell, F. E. (2001). Regression modelling strategies with applications to linear models, logistic regression, and survival analysis. New York: Springer.

Hill, M. O., \& Gauch, H. G. (1980). Detrended correspondence analysis-an improved ordination technique. Vegetation, 42, 47-58.
Hurlbert, S. H. (1971). The nonconcept of species diversity: a critique and alternative parameters. Ecology, 52, 577-585.

Karban, R., \& Baldwin, I. T. (1997). Induced responses to herbivory. Chicago: University of Chicago Press.

Körner, C. (2003). Alpine plant life. Functional plant ecology of high mountain ecosystems. Berlin Heidelberg: Springer.

Kruess, A., \& Tscharntke, T. (2002). Contrasting responses of plant and insect diversity to variation in grazing intensity. Biological Conservation, 106, 293-302.

Lavorel, S., McIntyre, S., Landsberg, J., \& Forbes, T. D. A. (1997). Plant functional classifications: from general groups to specific groups based on response to disturbance. Trends in Ecology and Evolution, 12, 474-478.

Le Cessie, S., \& Van Houwelingen, J. C. (1991). A goodness of fit test for binary regression models, based on smoothing methods. Biometrics, 47, 1267-1282.

Lindsey, J. K. (1999). Models for repeated measurements. Oxford: Oxford University Press.

Loe, L. E., Mysterud, A., Stien, A., Steen, H., Evans, D. M., \& Austrheim, G. (2007). Positive short term effects of sheep grazing on the alpine avifauna. Biology Letters, 3, 109-111.

Martin, T. G., Wintle, B. A., Rhodes, J. R., Kuhnert, P. M., Field, S. A., Low-Choy, S. J., et al. (2005). Zero tolerance ecology: improving ecological inference by modelling the source of zero observations. Ecology Letters, 8, 1235-1246.

Melis, C., Buset, A., Aarrestad, P. A., Hanssen, O., Meisingset, E. L., Andersen, R., et al. (2006). Impact of red deer Cervus elaphus grazing on bilberry Vaccinium myrtillus and composition of ground beetle (Coleoptera, Carabidae) assemblage. Biodiversity and Conservation, 15, 2049-2059.

Melis, C., Sundby, M., Andersen, R., Moksnes, A., Pedersen, B., \& Røskaft, E. (2007). The role of moose Alces alces L. in boreal forest - the effect on ground beetles (Coleoptera, Carabidae) abundance and diversity. Biodiversity and Conservation, 16, 1321-1335.

Mobæk, R., Mysterud, A., Loe, L. E., Holand, Ø., \& Austrheim, G. (2009). Density dependent and temporal variability in habitat selection by a large herbivore; an experimental approach. Oikos, 118, 209-218.

Moen, A. (1998). National atlas of Norway: vegetation. Hønefoss: Norwegian Mapping Authority.

Morris, M. G. (2000). The effects of structure and its dynamics on the ecology and conservation of arthropods in British grasslands. Biology Conservation, 95, 129-142.

Mysterud, A., \& Austrheim, G. (2005). Ecological effects of sheep grazing in alpine habitats. Shortterm effects. Utmarksnaring $i$ Norge, 1-05, 1-91.

Mysterud, A., Hansen, L. O., Peters, C., \& Austrheim, G. (2005). The short-term effect of sheep grazing on selected invertebrates (Diptera and Hemiptera) relative to other environmental factors in an alpine ecosystem. Journal of Zoology, 266, 411-418.

Mysterud, A., Iversen, C., \& Austrheim, G. (2007). Effects of season, density and weather on use of an altitudinal gradient by sheep. Applied Animal Behaviour Science, 108, 104-113.

Pöyry, J, Luoto, M., Paukkunen, J., Pykälä, J., Raatikainen, K., \& Kuussaari, M. (2006). Different responses of plants and herbivore insects to a gradient of vegetation height: an indicator of the vertebrate grazing intensity and successional age. Oikos, 115 , 401-412.

Pringle, R. M., Young, T. P., Rubenstein, D. I., \& McCauley, D. J. (2007). Herbivore-initiated interaction cascades and their mod- 
ulation by productivity in an African savanna. Proceedings of National Academic Science of United Sates of America, 104, 193-197.

R. Development Core Team. (2008). R: a language and environment for statistical computing. Vienna, Austria: R Foundation for Statistical Computing.

Rekdal, Y. (2001). Vegetation and forage at Minnestølen. NIJOSdokument, 23/01, 1-21.

Rødven, R., Männikkö, I., Ims, R. A., Yoccoz, N. G., \& Folstad, I. (2009). Parasite intensity and fur coloration in reindeer calves-contrasting artificial and natural selection. Journal of Animal Ecology, 78, 600-607.

Sanders, H. (1968). Marine benthic diversity: a comparative study. The American Naturalist, 102, 243-282.

Sigmond, E. (1998). Odda map of rock; Odda; 1:250 000. Norwegian Geological Surveys, Trondheim.

Sjödin, N. E., Bengtsson, J., \& Ekbom, B. (2008). The influence of grazing intensity and landscape composition on the diversity and abundance of flower-visiting insects. Journal of Applied Ecology, 45, 763-772.

Steen, H., Mysterud, A., \& Austrheim, G. (2005). Sheep grazing and rodent populations: evidence of negative interactions from a landscape scale experiment. Oecologia, 143, 357-364.

Stewart, A. J. A. (2001). The impact of deer on lowland woodland invertebrates: a review of the evidence and priorities for future research. Forestry, 74, 259-270.

Suominen, O., \& Danell, K. (2006). Effects of large herbivores on other fauna. In K. Danell, R. Bergström, P. Duncan, \& J. Pastor (Eds.), Large herbivore ecology, ecosystem dynamics and conservation. Cambridge: Cambridge University Press.
Suominen, O., Niemelä, J., Martikainen, P., Niemelä, P., \& Kojola, I. (2003). Impact of reindeer grazing on ground-dwelling Carabidae and Curculionidae assemblages in Lapland. Ecography, 26, 503-513.

Suominen, O., Persson, I.-L., Danell, K., Bergström, R., \& Pastor, J. (2008). Impact of simulated moose densities on abundance and richness of vegetation, herbivorous and predatory arthropods along a productivity gradient. Ecography, 31, 636-645.

Ter Braak, C. J. F, \& Smilauer, P. (2002). CANOCO reference manual and CanoDraw for Windows user's guide: software for canonical community ordination (version 4.5). Ithaca, New York: Microcomputer Power.

Uetz, G. W., \& Unzicker, J. D. (1976). Pitfall trapping in ecological studies of wandering spiders. Journal of Arachnology, 3, 101-111.

Vesk, P. A., Leishman, M. R., \& Westoby, M. (2004). Simple traits do not predict grazing response in Australian dry shrublands and woodlands. Journal of Applied Ecology, 41, 22-31.

Violle, C., Navas, M.-L., Vile, D., Kazakou, E., Fortunel, C., Hummel, I., et al. (2007). Let the concept of trait be functional!. Oikos, $116,882-892$.

Warui, C. M., Villet, M. H., Young, T. P., \& Jocqué, R. (2005). Influence of grazing by large mammals on the spider community of a Kenyan savanna biome. Journal of Arachnology, 33, 269-279.

Westoby, M., Falster, D., Moles, A. T., Vest, P. A., \& Wright, I. J. (2002). Plant ecological strategies: some leading dimensions of variation between species. Annual Review of Ecology System, $33,125-159$.

Westoby, M., \& Wright, I. J. (2006). Land-plant ecology on the basis of functional traits. Trends in Ecology and Evolution, 21, 261-268.

Available online at www.sciencedirect.com 